\title{
The Role of Input, Interaction and Output in the Development
}

\section{of Oral Fluency}

\author{
Shumei Zhang \\ Foreign languages Department, Dongguan University of Tech \\ Song Shan Lake, Dongguan, Guangdong 523808, China \\ E-mail: zhangsm@dgut.edu.cn
}

\begin{abstract}
This paper is a research in the second Language acquisition (SLA) with its focus on the role of input, interaction and output in the development of oral fluency in the EFL context from both a theoretical point of view and a case study. Two instruments were used: tests of oral fluency and face-to-face interviews. The findings showed that non-native oral fluency could be obtained through efficient and effective input, interaction and output in EFL while on the other hand they suggested answers to the question why most Chinese English learners failed to speak English fluently, namely lacking effective input and output, having no real need for interaction, attaching too much importance to language forms and written tests.
\end{abstract}

Keywords: Input, Interaction, Output, Oral fluency

\section{Introduction}

Since 1978 when the then Chinese government leaders decided to adopt the reform and open-door policies, English language learning has been boosted in China. In the past three decades, the Chinese English learner has greatly improved their four basic skills-listening, speaking, reading and writing. However, these four skills have not developed at the same rate. $\mathrm{Li}(2003)$ holds that speaking remains the most difficult skill to master for the majority of English learners. They are still incompetent to communicate orally in English even though they might be able to read Shakespeare's works in original after years of study at school. What accounts for this inability? Is it possible for a nonnative speaker to possess near native-like proficiency? Such questions have interested me for years and consequently prompted me to choose this topic and conduct the present research.

The research is a study on the second Language acquisition (SLA) with its focus on the role of input, interaction and output and discusses their influence on the development of oral fluency. As the subjects have learned English in an input-poor EFL context, what it is reflected in this study somewhat represents the problems that have arisen from EFL learning. Hopefully, the present research in the role of input, interaction and output and their influence on oral fluency should enhance the understanding of the nature of speaking, an indicator of L2 proficiency, and the understanding of the relationship between learners and factors that influence their SL acquisition.

In this paper I will start by eliciting different viewpoints about the role of input, interaction and output in L2 learning, before defining oral fluency. After that I will present the data collected from an experiment of 15 Chinese young learners, especially from two types of English learners and their learning history that contributed to their oral ability. At the end of the paper I will make a conclusion by summarizing the findings from the experiment and state my opinion about the role of input, interaction and output in the development of learners' oral fluency.

\section{Literature view}

\subsection{Input, Interaction and Output}

The role of the three closely relevant factors, namely input, interaction and output has gradually been acknowledged in second language (L2) learning. It is now widely recognized that input is essential for language acquisition. In addition to input, it is also accepted that interaction plays a crucial role in the process of learning L2. Output--an automatic output, to be exact--is one pedagogical goal in learning L2. So, input, interaction and output are three essential compositing elements in L2 acquisition. But for years there has been a debate about their role.

\subsubsection{Input}

In language learning, input is the language data which the learner is exposed to. It is commonly acknowledged that for second language acquisition to take place there must be two prerequisites: L2 input available to the learners and a set of internal mechanism to account for how L2 data are processed (Ellis, 1985). Towards the issue of input there are generally three views: behaviorist, mentalist and interactionist view, each holding a different emphasis in explaining SLA. A behaviorist view treats language learning as environmentally determined, controlled from outside by the stimuli 
learners are exposed to and the reinforcement they receive. In contrast, mentalist theories emphasize the importance of the learner's 'black box'. They maintain that learners' brains are especially equipped to learn language and all that is needed is minimal exposure to input in order to trigger acquisition (Ellis, 1997). Interactionist theories acknowledge the importance of both input and internal language processing, emphasizing the joint contribution of linguistic environment and the learners' inner mechanism in interaction activities, which I will discuss later.

Krashen was an important figure whose input hypothesis once exercised powerful influence on SLA. According to his input hypothesis, SLA takes place when the learner understands input that contains grammatical forms that are at ' $\mathrm{i}+1$ ' (i.e. are a little more advanced than the current state of the learner's interlanguage). He suggests that the right level of input is attained automatically when interlocutors succeed in making themselves understood in communication (Krashen, 1985:2). In his view, the Input Hypothesis is central to all of acquisition, i.e. L2 acquisition depends on comprehensible input. In the classroom, then, the teacher's main role is to ensure that learners receive comprehensible input by providing them with listening and reading materials. However, a great many researches later challenge his hypothesis by supplying abundant evidence indicating that though necessary, comprehensible input alone is insufficient for L2 acquisition (Swain 1981,1991; Harley \& Hart, 1997; Harley \& Swain, 1984, etc.). They argue that processing of comprehension is different from processing of production. And the ability to understand meaning conveyed by sentences differs from the ability to use linguistic system to express meaning (Swain, 1985, 1988; Sharwood Smith, 1986; Crookes, 1991). When input is negotiated and learners produce output in interaction, they selectively "take in" portions of comprehensible input and choose correct linguistic form to express themselves. This process makes it possible for the learners to internalize what they have learnt and experienced.

Corder's distinction between input and intake should be mentioned here. He defines input as what is available to the learner, whereas intake refers to what is actually internalized by the learner (Corder, 1967).This distinction is justified by huge amount of evidence in foreign language learning practice. It is convincingly argued that L2 acquisition will not occur even if with input at the right quantity and quality but without being internalized by the learners and becoming part of their interlanguage system.

On the whole, input is absolutely necessary and there is no theory or approach to SLA that does not recognize the importance of input. In Schwartz's view (1993), the input feeds or nurtures an innate system to aid its growth. But input alone cannot facilitate second language learning. It will not function to the full in SLA until it gets involved in interaction.

\subsubsection{Interaction}

Interaction refers to exchanges in which there is some indication that an utterance has not been entirely understood and participants need to interrupt the flow of the conversation in order for both parties to understand what the conversation is about (Gass \& Selinker, 2001). In conversations involving NNSs, negotiations are frequent. Long(1980) was the first to point out that conversations involving NNSs exhibited forms that did not appear to any significant degree when only NSs were involved. For example, confirmation checks, comprehension checks and clarification requests are prepared throughout conversations in which there is a nonproficient NNS participant. In his updated version of the interaction Hypothesis, Long(1996) suggests that "negotiation for meaning, and especially negotiation work that triggers interaction adjustments by the NS or more competent interlocutor, facilitates acquisition because it connects input, internal learner capacities, particularly selective attention, and output in productive ways" (pp.451-452). Thus , through negotiation, a learner's attentional resources may be oriented to (a) a particular discrepancy between what he or she knows about the L2 and what the L2 really is or (b)an area of the L2 about which the learner has little or no information(Gass \& Torres, 2005). Interaction is said to be an attention-drawing device, which means that interaction serves to draw attention to an unknown part of language (Gass, 1977). Learning may take place during the interaction.

Allwright (1984:156)regards interaction as the "fundamental fact of classroom pedagogy" because "everything happening in the classroom happens through a process of live person-to-person interaction". During such kind of interaction learners make efforts to generate comprehensible output, which turns to be sources of input for other interlocutors. Misunderstandings occur frequently in interaction due to different factors, which can be, on different occasions, phonological, syntactic, vocabulary, contextual or cultural, to name only a few. To get meaning through, or seek correct interpretation, or make up for communication breakdown, the learners resort to all sorts of strategies. The feedback the learners get from their teachers and peers drives them to "test their hypotheses and refine their development knowledge of the language system" (Hedge, 2000); hence functions as a facilitator of language development.

Other SLA theorists regard interaction as the bedrock of acquisition based on the theories of L. S. Vygotsky, a Russian psychologist, who argues that children learn through interpersonal activity, such as play with adults, who provides 'scaffolding', whereby they form concepts that would be beyond them if they were acting alone. In this respect, the notion of the zones of proximal development is important, which are created through interaction with more knowledgeable others. As a result of interaction, the child learns how to control a concept without the assistance of 
others (Ellis 1997).

In sum, input and interaction may facilitate the development of the natural route of SLA in that comprehensible input resulted by means of interaction adjustments by the NS or more competent interlocutor. Then, what is the role of output in SLA?

\subsubsection{Output}

Output is the language a learner produces. Swain, the most influential figure for Output Hypothesis, has argued that comprehensible output also plays a part in L2 acquisition. She pointed out early in 1985 that only when learners are "obliged" to produce comprehensible output otherwise comprehensible input alone is insufficient to L2 learning process. According to her there is no better way to test the extent of one's knowledge (linguistic or otherwise) than to have to use that knowledge in some productive way-whether it is explaining a concept to someone (i.e. teaching) or writing a computer program, or in the case of language learning, getting even a simple idea across, and in doing so, he might modify a previous utterance or he might try out form that he had not used before. However, prior to her important paper in 1985, output was traditionally viewed as a way of producing what had previously been learned and the idea that output could be part of the learning mechanism itself was not seriously contemplated(Gass \& Selinker 2001). Then in 1995, she stated that output might stimulate learners to move from the semantic, open-ended, nondeterministic, strategic processing prevalent in comprehension to the complete grammatical processing needed for accurate production. Output, thus, would seem to have a potentially significant role in the development of syntax and morphology.

Gass (2001) summarizes the four functions of output in L2 learning based on Swain's ideas: testing hypothesis about the structures and meanings of L2; receiving crucial feedback for the verification of these hypotheses; forcing a shift from more meaning-based processing of the second language to a more syntactic mode; and developing fluency and automaticity in interlanguage production.

The last significant function of output is to create greater automaticity, which is one pedagogical goal in SLA. Little effort is required to execute an automatic process( involved when the learner carries out the task without awareness or attention) as it has become routinized and automatized just as the steps involved in walking towards a bike, getting out the key, unlocking it, pushing it, getting on it and riding it, requiring little thought and less time. Mclaughlin (1987:134) claimed that automatization involves "a learned response that has been built up through the consistent mapping of the same input to the same pattern of activation over many trials." Here this notion is extended to output, meaning that consistent and successful mapping or practice of grammar to output results in automatic processing (Loschky \& Bley-Vroman, 1993).

In many researchers' opinion, automaticity benefits learning. Firstly, as automatic processing consumes fewer attentional resources than does controlled processing (involved when conscious effort and attention is required to perform a task), the more automatic performance becomes the more attentional resources left over for other purposes. For example, if one can handle the phonology and syntax of a second language automatically, then more attention can be paid to processing semantic, pragmatic, and sociolinguistic levels of communication. Secondly, when a mechanism becomes automatic it will process information very quickly and accurately. Thirdly, there are strong reasons for associating automaticity with important aspects of fluency (Skehan, 1998; Hulstijn, 1997,etc). Then what is fluency?

\subsection{The Definition of Fluency}

Many researchers in SLA have attempted to define it. Fluency represents the ability to speak or read quickly, accurately, and without undue hesitation, then automatic execution of certain aspects of L2 performance such as pronunciation, grammatical processing, and word recognition would, by definition, promote fluency (Skehan, 1998). Here, oral fluency is of my interest, for speaking, an indicator of L2 proficiency is the most difficult skill for English learners in China to master. According to Faerch et al. (1984), oral fluency is a relative conception, which in FL learning means the ability a learner has to express his or her thoughts freely and easily. They classified these abilities into three types: semantic fluency, lexical and syntactical fluency, and phonetic fluency. Brumfit (1984:42), on the other hand, assumed that fluency was "the maximally effective operation of the language system so far acquired by the student". He hypothesized that fluency was not only applicable to speech production (speaking and reading) but also to speech distinction (listening and reading). Sajavaara (1987) held that besides the skills they needed, speech production and speech distinction were also affected by a number of social and cultural factors. Therefore, two dimensions should be considered in the explanation of fluency: acceptability and continuity. Meisel (1987), in support, insisted that fluency be defined in terms of communicative acceptability.

A more influential definition was proposed by Fillmore (1979), who discussed fluency in terms of oral production and distinguished four abilities manifested in L1 oral fluency. According to him, a thorough consideration should be given to "fluency", "correctness", "flexibility" and "creation", the four abilities involved in language production when oral fluency is measured. Skehan (1996) also stressed that fluency should not be separated from meaning conveyed by sentences because it reflected the learner's ability to cope with real communicative events. 
Based on Parrott (1993)), oral fluency in the present paper is operationally defined as the ability to communicate an intended message; to adjust the messages according to the responses of the listener; to produce coherent utterance and stretches of speech; to respond and speak with continuity; and to use strategies to aid communication when the appropriate vocabulary or grammar is not available.

\section{Method}

\subsection{Hypothesis}

The hypothesis in this study is that non-native oral fluency can be obtained through efficient and effective input, interaction and output in a foreign language setting.

\subsection{Subjects}

The subjects participating in this study were 15 young Chinese-speaking English learners who had learned English for four or five years. They ranged in age from 9 to 13. They learned English in different schools on weekdays while at weekends they received extra 2-hour English training program in a private training center, where this study was carried out. The reason why they were chosen as the subjects is that all of them had been using the textbooks which highlight learners' communicative skill development under the guidance of the present national English curriculum, that most of them were the best at English or among the best in their school classes with their latest mid-term English test scores above 90 (maximum possible score is 100), i.e. this group of learners were not weak ones who needed remedial class in order to keep up their studies, and instead they came with the ambition to remain the best in their classes and then enter the key universities, and that their parents attached great importance to their English learning, doing their best to provide them with what they needed in English learning.

\subsection{Instruments}

Three instruments were used to gather the data for this study: (i) a test of oral fluency among all the subjects; (ii) a second test of oral fluency between the two subjects who stood out in the first one; (iii) face-to-face interviews. The detailed descriptions of each instrument are as follows:

Instrument 1: In order to evaluate all the subjects' oral fluency, I decided to let each of them take the oral test by saying something which was related to their lives regardless of their personal details, that is, age, family background, school where they studied and time they spent in learning English. Considering they had just learned the past tense in the training center, I chose the topic "What happened to you yesterday?" The task was carried one by one in a quiet room in the form of face-to-face interactions with me, but with the focus on the learners' productive skills I only encouraged them to think aloud about what they had done on the previous day by saying "first, then, after that..."occasionally.

In assessing each learner's performance, I used the following criteria, which were adapted from those specified in the RSA Test battery: (a) range of language forms which the learner can make use of, (b) accuracy in the production of the language forms (production, intonation, stress, grammatical and lexical features), (c), appropriateness in the use of the language forms to convey meaning in specific context, (d) length and complexity of the learner's production, (e) fluency in conveying the spoken language $(\mathrm{Li}, 2003)$.

I recorded each carrying out the task and later I made written transcription of their answers to the question. All participants could say something and were fluent in conveying their thoughts, but so far as the range of the language forms is concerned, what they were able to use was limited and static, for example, most of them repeated the same sentence structure, i.e. SVO, by saying "I did my homework. I watched TV. I surfed the internet..." Among other things, three participants used the present continuous tense (for example, "I am playing the piano") and simple present tense (for example, "I go to the shopping mall.") in the situation where they should have used the simple past tense. One participant generally used each verb with just one of these tenses from the beginning to the end of his speech. Among 15 subjects, two learners named David and Snow stood out, for they spoke with comparative length and complexity and fewer errors. Following are their oral descriptions of what they did on the previous day.

\section{David's:}

Yesterday I went to have a Christmas dinner in Dongchen International Hotel. At there I eat some sandwich, drink some orange juice and I eat a lot of pork. It was very delicious. After the meal, we went to the cinema. At the cinema, we watched a great film. It is about aliens. After watching the film, we go back home and played chess. Dad was always winning me. So I wish I could win him someday. After playing chess, we played table tennis. I beat him, but he can't afford my attack. So he can not beat me in table tennis, but can only beat me in the chess. It is a great day.

Snow's:

Yesterday morning I got up at half past six as usual. Then I made my bed and washed my face. Finished that, I had breakfast, and then I played computer, watched TV and did my homework. I go to bed at 11.

The italicized words are the errors they made. From time to time David failed to give the correct forms of irregular past 
tense such as 'ate, drank, went and couldn't' while Snow made one error in this respect. The other errors are the redundant prepositional word 'at' before the adverb 'there' and 'Finished', which should have been 'Finishing'. Apart from these errors, they used other language forms accurately. Besides, both of them expressed their thoughts freely, easily and without undue hesitation. But so far as the descriptive information given by them, David's is more vivid and dynamic, being rich in tense and words while Snow's is static, dull, vague and general, lacking variety of words and sentence structures. Thinking Snow might really have a dull time on that day and had nothing interesting which was worth mentioning, I decided to give both of them a second test to try their oral ability.

For the second test, two subjects David and Snow were asked to read a passage silently and then retell it. Similar to the first one, the task was carried respectively. Either of them was given 2 minutes for silent reading and then retold it immediately afterwards, without looking back at the passage.

Because the research concerned successful input and output, I had to find a text that contained $98 \%$ of words that the participants would know. The text also had to match the comprehension ability of the young learners. The passage(see Appendix A) contained 151 words in length, which as long as the texts they learned in the training center. To determine the appropriateness of the passage in terms of its reading level and content, I piloted the passage with a group of junior two middle school students assumed to be similar to participants with respects to language proficiency and level of reading comprehension. The students were asked to underline any words they didn't know. All of them reported that court case were the words unknown. The pilot study revealed that the students had a good comprehension of the text.

I made recordings and the following are the written transcriptions of their story retelling.

David's:

Mr. Gray was a hunter. He always goes to hunt, but he was not good at shooting wild animals and his eyes were not good, either. One time when he was together with his hunters he shot one of the hunters. And the hunter that was shot said: "You shot at me. Why? In the layer's office, (a little pause), in the lawyer's place, the lawyer asked: "Why did you shoot (at) him?" Mr. Grey answered: "I thought he was a bear." "When did you realize that you were wrong?" asked the lawyer. "After the bear shooting (at) me back."

Snow's:

Mr. Grey like shooting very much. And...hum...and.. But he didn’t get much practice at shooting at animals. One of his troubles was...hum ...

David spent 15 seconds reading the passage silently and then closed the storybook to start retelling it confidently. He seemed to be an experienced English reader. He read very fast and had little difficulty understanding the content. Within 15 seconds, he read for information by constantly jumping from individual words and immediate contexts, for example, "when it rained and his glasses got wet," to make a global sense of the passage by saying, for example, "His eyes were not good," in his quick and fluent output. At the same time, he paid attention to the new word court and its meaning. By guessing from the whole passage, he succeeded in communicating the idea of it by inventing his own saying 'the lawyer's place'. Obviously he already possessed some communicative strategies that can help him make effective use of his L2 knowledge.

Snow read the passage silently for 2 minutes and then unwillingly closed the book. She was only able to say the beginning of the story before she stopped by saying "Sorry, I don't know what happened next." I could see she tried to recite the story word by word from memory, which was a difficult task within two minutes. After I switched off the recorder, she told me she understood the story but she just didn't know how to express it in English. In this case, I asked her to retell it again from the beginning in Chinese. She did it very well. She even knew the exact Chinese meaning of the two new words court case. Her problem lies in producing output.

\section{Instrument 2: Interviews}

To find out whether there was anything in their leaning history that may account for what has been found, I conducted the interviews one week later, which were individualized. To obtain accurate information on their English learning while not overburdening the participants with L2 processing, I interviewed the two subjects in Chinese while David, being much younger, was accompanied by his mother. The interview questions (see appendix B) and data shown below are English translations.

Characteristic

Age

School

Grade

Years of study English
David

9

a private foreign language school

5

6
Snow

13

a state-owned school

8

5 


\section{English classes each week}

The latest English score(\%) at school

Help available at home

Watching English TV

Reading English

Speaking English

Native speakers available

Participation in English competitions

Father's occupation

Mother's job

\subsection{Findings}

\subsubsection{David}

About David's English learning history, his mother said as follows:

Firstly, David was fond of reading. He read everything he could reach at home including his elder sister's senior middle school English textbooks. He never read the book that interested him for just once. Instead, he read it for at least three times to internalize it by being one of the characters in it. While reading he never consulted dictionaries, occasionally he might ask his sister and family tutors for help. For most part of time he sought for information available in the pictures beside the words and attempted to infer the meanings of unknown words which he encountered by studying the pictures in combination with his awareness of context and his limited relevant linguistic knowledge. He would often watch the English movies, which were based on the books he read, and talked about them with both his family and Chinese or foreign friends. From what was uttered or mumbled from his mouth, you might know what kind of books he had been reading, his mother said.

Secondly, David had learned English from native English speakers for years both at school and at home. In his home, I recorded the following conversation carried between him and his school English teacher, a young American man, who came once a week and stayed there playing with him while instructing him informally for about 2 hours each time.

Teacher (T): What does your grandmother do?

David: She has no job now.

T: Why not? Is she retired?

David: Yeah. She is very old. She is over seventy.

T: Where did she use to work?

David: Hm hm. I am not sure. Maybe in a bank.

T: Do you know that bank? The name of the bank is...

David: Yeah The Bank of China.

T: That's a world-famous bank. Then do you want to be a bank clerk? Do you want to work in the bank?

David: No, because I am not rich enough.

T: What do you mean by saying that you are not rich enough, David?

David: I will have to pay trillions of dollars. I need six trillions to make a bank.

T: You mean you want to have a bank of your own.

David: Yes. I need that money. I will have to lend that money.

T: Will you lend it or borrow it? Lend or borrow?

David: I will first have to borrow it from others and then I will make money by lending it to others...

The extract above is an example of the interaction between David and his teacher. In the conversation, the teacher interrupted the flow of the conversation in order to confirm what David was talking about while drew David's attention to the difference of lend and borrow, which is confusing to most southern Chinese English learners because of the effect of the transfer from L1 to L2. In the course of so doing, the teacher might assist David in English learning and thus David's English knowledge was developed gradually.

Then, his mother said that he was a fearless confident learner, willing to struggle to communicate in English, even when 
he had very limited resources. Gradually he became more confident and independent. He loved English. He was always ready to approach to native English speakers whom he met in public places, such as restaurants, stores and parks to have conversations with them. As a cute-looking polite little boy, he had never been left out in the cold on these occasions. At school, he willingly acted as the interpreter of his English teachers who couldn't speak Chinese; and he was never timid to go to attend any English class open to him at school, usually in higher grades, which suited his level and interest, with the school authority's permission.

David's parents had never been abroad and only knew a few English words but they tried every possible way to create English-like learning environment for him, for example, by sending him to expensive private foreign language kindergartens and schools at the age of four; regularly negotiating with the school leaders and teachers about his study; buying all kinds of English books and movies CDs for him; hiring either Chinese English tutors or American English ones to help him learn English at home; and moving to a residential area where he could make friends and play with the children from English-speaking countries.

As a more socially advantaged learner in the sample, David had more resources available to him than other Chinese learners. He had been learning English for six years even though he was just nine years old. Having eight English classes each week and many English books to read and English movies to watch, he had got much exposure to English. Learning English from and communicating with native English speakers provided him the chance to listen to and speak authentic English and get feedback from his teachers and friends to test his hypotheses and refine his knowledge of the language system. The fact that her mother was the owner of a training center where English was one of the major subjects ensured the availability of books and chances to get to know English when he was very young and contributed to the type of education he received.

In both instructed and noninstructed settings David developed his oral English proficiency. That's why his English was the best among all the participants studied. In 2005, according to his mother, he qualified for the National Outlook Oral English Competition after performing well at the provincial one and he won the silver medal in kids' group. Because of the success he had greater incentive to work harder at English.

\subsubsection{Snow}

Like the majority of Chinese learners in state-owned schools, Snow started to learn English from Grade three at the age of 9 and had 3 English classes each week at primary school and then 5 classes at junior middle school with Chinese English teachers teaching her only. With more than 50 students in her class, the class was rigidly dominated by the teacher who explained the texts either in English or in Chinese with the detailed explanations of the meaning of new words and phrases and long difficult sentences while the students sat quietly listening and taking notes, leaving little room for the students to speak. In class there was not much interaction between learners and teachers and peers themselves. High-staked exams, which mostly tested students' writing and reading competence, would decide what the student learned and how the teacher taught. It seems the requirements of the National Curriculum had not been taken into consideration and action. As a result, Snow didn't have much chance to practice speaking at school.

Like the majority of Chinese learners, after school, owing to work assignment which occupied all of her free time she didn't spend much time reading English and watching English movies, and she had no tutor who could help her improve her oral expression at home, and she couldn't contact any native English speakers in the place where she lived, either. As her father was busy with his business and mother was busy doing housework, she had to deal with all study matters by herself. She was timid to open a conversation with foreigners from other countries when she met them in public places, and thus a great many chances to practice speaking passed away from her.

In one word, her learning context did not provide her with adequate input, output and interaction with more knowledgeable others. Therefore, she consciously chose to emphasize highly intensive intentional textbooks learning. She was course-centered. Her ambition was to excel in examinations. Her priority was to fulfill all the requirements of the textbooks. In 2005, as a successful English learner in her class because she did well in number of exams she was chosen as one of those to represent her school to take part in the National Junior Middle School Grade Two Students' English Competence Competition but she won no prize.

Snow and David correspond almost precisely to the two types of English learners. First, they started to learn English at different ages. David began at four while Snow, a very typical Chinese learner, at nine. The second difference between them was their learning environment. David had much exposure to English and a lot of opportunities to speak English while Snow learned textbooks only with little chance to communicate with others in English. The third difference is their leaning style. Snow was meticulous about details and focused mainly on textbooks whereas David focused on reading and enjoying extracurricular material. Motivation was another area of difference. Snow was learning to excel whereas David was learning because of his intrinsic interest in English. Snow preserved, and David enjoyed his learning process. Snow spent a great deal of time learning through the passage because intensive reading had been her main source of English input. David, on the other hand, spent less time on textbooks but much more time on extensive 
reading, which ensured the natural recurrence of words and sentences he tried to learn in his growth as people as he acquired a foreign language.

\section{Discussions of Findings}

4.1 SLA literature shows that comprehensible input, interaction and output play an essential role in L2 acquisition. The present study suggests that it is possible for a non-native speaker to possess near native-like proficiency in a foreign language setting if he or she has adequate and effective input, interaction and output. This is quite in agreement with the theories of Krashen's exposure to input, Long's interaction and Swain's comprehensible output. If Snow had been exposed to a wide variety of uses of English, and had had interactions with native English speakers or more knowledgeable ones, she could possibly have obtained native-like oral fluency, too. In the second instrument of the case study, she understood the reading passage very well, but after reading she could not express it in her own words. According to Swain, Plann, Harley \& King, the ability to understand meaning conveyed by sentences differs from the ability to use linguistic system to express meaning. Besides more exposure to input, Snow needs plenty of practice in speaking. In a foreign language setting the only way to improve oral expression is to make the most of the situations available for speaking just as David did in the case study. And classroom training alone is far from sufficient. Students need to do more beyond what was taught in class.

4.2 Reading extensively is found to be the single most important source of English input in the foreign language setting. Its aim is mostly two folded in learning: reading to comprehend English and reading to learn English. However, on the one hand, many English learners ignore its another important function, i.e. it facilitates speaking by enlarging their knowledge and providing them with more topics to talk about. English should not be only as a subject to be learned, but as a means of communication as well. Not many realize it's the opportunity to improve speaking by telling others orally what they have read. According to the SLA theories, comprehensible input alone is not enough and when input is negotiated, the learners will possibly internalize what they have learned and experienced. On the other hand, while reading many students tend to focus on syntax and vocabulary and as a result the flow of reading may be interrupted, important information may be ignored and the passage may not be comprehended as a whole. After reading the passage, they may not be able to express its main idea and significant factors orally with fluency. In fact, the poor speaking ability of English learners is not due to their inadequate command of English syntax and vocabulary; but it is due to their too much emphasis on vocabulary, idiomatic usage and sentence structure. David's success suggests that reading for information and reading to talk about it should be one of the aims sought by learners to practice their English in a foreign language setting.

4.3 The critical period (before puberty) hypothesis is found to function when explaining individual difference. Sufficient input before the age of twelve makes L2 acquisition easy and complete. If a child is not exposed to a language, i.e. to hear it or see it in the case of sign language at the right time he or she will not learn it. This is quite in agreement with the theories of the behaviorist and exposure to input. Millie, one subject of the case study in the paper began to learn English at four but she was still poor orally in communicating because of her insufficient exposure to English. One boy in my college English class didn't start to learn English until twelve when he became a middle school student and after many years of efforts, he was able to speak English fluently but with very strong L1 accent, which was very difficult for him to get rid of no matter how hard he tried. He might never be able to achieve a native-like accent unless he had been exposed to it at an early age. For L2 learners, when is the best time to start to learn it? The answer maybe is the younger, the better.

4.4 The role that conversational interaction between native and non-native speakers plays is found to be dynamic in the development of a second language. This further confirms Long's point of view. It's suggested that learning process should involve native English speakers or at least Chinese English teachers with near native-like fluency, who are competent enough to provide 'scaffolding', which functions in recruiting the learner's interest, simplifying the task, highlighting its relevant features, maintaining motivation, controlling the learner's frustration, and modeling. (Wood, Bruner, \& Rose, 1976)

4.5 National exams, which have played an important role in nationwide English studies, and teachers, who put too much emphasis on vocabulary, idiomatic usage and sentence structure, should be partially responsible for oral inability. To speed up oral improvement, oral test needs to be extended and only in this way can teachers alter their attention to the practice of speaking.

\section{Conclusion}

This paper is a research in SLA with its focus on the role of input, interaction and output in the development of oral fluency in the EFL context from both a theoretical point of view and a case study. SLA literature shows that input, interaction and output play an imperative role in the development of oral fluency, which is supported by the results of the case study. A nonnative speaker is able to possess near native-like proficiency in the EFL context if he or she has plenty of time for learning English, adequate exposures to a wide variety of English both spoken and written, a real 
need to use English on a daily basis and interaction with more knowledgeable ones, not treating English as a subject to be learned, but as a means of communication, where the focus is on the meaning first, then on the form of the language.

In the research, learners' age, language aptitude, personalities, motivation, attention and learning strategies were also found to be very active. It's suggested that, in addition to input, interaction and output, there are some other factors affecting oral fluency and the procedure of second language acquisition is really very complicated. What are important factors and what are less important is hard to establish because they are closely related to each other and integrate to work on learners. However, what was found from this study may provide some insights into the importance of the role of input, interaction and output in SLA and the nature of speaking, though having its limitation owing to the small scale of the case study and the two learners reported in the study being young, and may serve as a basis for further research.

\section{References}

Allwright, R. (1984). The Importance of Interaction In Classroom Language Learning. Applied Linguistics 5: 156-71.

Brumfit, C. (1984). Communicative Methodology In Language Teaching. Cambridge University Press.

Corder, S. P. (1967). The Significance of Learners' Errors. International Review of Applied Linguistics.

Crookes, G. (1991). Second Language Speech Production Research: A Methodologically Oriented Review. Studies In Second language Acquisition, 13: 113-132.

Doughty, C. J. \& Long, M. H. (2003). The Handbook of Second Language Acquisition, Blackwell Publishing Ltd.

Ellis, R. (1985). Understanding Second Language Acquisition. OUP Oxford.

Ellis, R. (1997). Second Language Acquisition, Oxford University Press.

Fillmore, C. J. (1979). On Fluency: Individual Differences In Language Ability \& Language Behavior. Academic Press, Inc.

Gass, S. M. \& Selinker, L. (2001). Second Language Acquisition: An Introductory Course $2^{\text {nd }}$ edition, Lawrence Erlbaum Associates, Inc. New Jersey.

Gass, S. M. \& Torres, M. J. A. (2005). Attention When? Tesol Quarterly Cambridge University Press 0272-2631/05.

Harley, B., \& Hart, D. (1997). Language Aptitude and Second Language Proficiency In Classroom Learners of Different Starting Ages. Studies In Second Language Acquisition, 19: 379-400.

Harley, B., \& Swain, M. (1984). The Interlangage of Immersion Students and Its Implications for The Second Language Teaching. In A. Davies, C. Criper \& A. Howatt (Eds.), Interlanguage (pp.291-311)). Edinburgh: Edinburgh University Press.

Hedge, T. (2000). Teaching and Learning In The Language Classroom. Oxford University Press.

Hulstijin, J. (1997). Second Language Acquisition Research In The Laboratory: Possibilities and Limitations. Studies In Second Language Acquisition, 19:131-44.

Krashen, S. (1985). The Input Hypothesis: Issues and Implications. New York: Longman.

Li, R. (2003). Factors that Chinese Students Believe to Affect Their Oral Fluency. Teaching English In China. 52:23-27 Foreign Language Teaching and Research Press. Beijing.

Long, M. (1980). Input, Interaction and Second Language Acquisition. Unpublished doctoral dissertation, University of California, Los Angeles.

Long, M. (1996). The Role of the Linguistic Environment In Second Language Acquisition. In W. Ritchie \& T. Bhatia (Eds.). Handbook of Second Language Acquisition (pp.413-468). San Diego, CA: Academic Press.

Loschky, L., \& Bley-Vroman, R. (1993). Grammar and Tasked-based methodology. In G. Crookes \& S. Gass(Eds.), Tasks and language learning: Integrating theory and practice (pp.122-167). Clevedon, England: Multilingual Matters.

Mclaughlin, B. (1987). Theories of Second Language Learning. London: Edward Arnold.

Sajavaara, M. (1987). Second Language Speech Production: Factors Affecting Fluency. In H. D. Dechert \& M. Raupach (eds). Psycholinguistic Models of Production. New Jersey: Ablex.

Schwartz, B.D. (1993). On Explicit and Negative Data Effecting and Affecting Competence and Linguistic Behavior. Studies in Second Language Acquisition, 15:147-163.

Sharwood Smith, M. (1986). Comprehension versus Acquisition: Two Ways of Processing Input. Applied Linguistics, 7:239-256.

Skehan, P. (1996). A Framework for the Implementation of Task-based Instruction. Applied Linguistics 17:38-62.

Skehan, P. (1998). A Cognitive Approach to Language Learning. Oxford University Press. 
Swain, M. (1995). Three Functions Of Output In Second Language Learning. In G, Cook \& B, Seidlhofer(Eds.) Principles \& Practice In Applied linguistics. Oxford University Press.

Wood, D., Bruner, J.S. \& Ross, G.. (1976). The Role of Tutoring in Problem solving. Journal of Child Psychology and Psychiatry, 17, 89-100.

\section{Appendix A}

\section{The Reading Passage}

Mr. Grey liked shooting very much, but he did not get much practice at shooting wild animals, and he was not very good at it. One of his troubles was that his eyes were not very good and he had to wear glasses. When it rained and his glasses got wet, he could not see very well.

One day he was invited to go to shooting bears in the mountains. It was rather a rainy day and by mistake Mr. Grey shot at one of the other hunters and hit him in the leg.

There was a court case about this, and at it the lawyer for the other man said, "Why did you shoot at Mr. Robinson?"

Mr. Grey answered, "I thought that he was a bear."

"When did you realize that you are wrong?" the lawyer asked.

"When the bear began to shoot back at me," Mr. Grey answered.

\section{Appendix B}

Interview Questions:

1, How old are you?

2 , Which school do you study in?

3, Overall, how do you see yourself as a language learner?

4, How many years have you learned English?

5, Do you have anyone help you to study English at home?

6, Do you often watch English TV programs?

7, Do you often read English books?

8, Do you often speak English in daily life?

9,Whom do you speak English to?

10, What do you do when you don't know how to express yourself in English?

11 ,What do you do when you don't understand them?

12, Do you have any native English speakers teach you English?

13, How many English classes have you each week at school?

14,Are you active in class? Do you have many chances to speak English in class?

15, Have you taken part in any English competitions? How many times? Have you won any prize?

16 , What do your parents do? 